\title{
Management of Animal Carcass Disposal Sites Using a Biochar Permeable Reactive Barrier and Fast Growth Tree (Populus euramericana): A Field Study in Korea
}

\author{
Jung-Hwan Yoon ${ }^{1}$, Young-Nam Kim ${ }^{1,2}$, Dong-Chun Shin ${ }^{3}$, Kwon-Rae Kim ${ }^{4}$ and \\ Kye-Hoon Kim ${ }^{1, *}$ \\ 1 Department of Environmental Horticulture, University of Seoul, Seoul 02504, Korea; \\ yoonfnfg@hanmail.net (J.-H.Y.); youngnam.a.kim@gmail.com (Y.-N.K.) \\ 2 Department of Ecology, Lincoln University, Lincoln 7647, New Zealand \\ 3 BYUCKSAN Engineering, Seoul 07286, Korea; dcshin@bseng.co.kr \\ 4 Department of Agronomy \& Medicinal Plant Resources, Gyeong Nam National University of Science and \\ Technology, Jinju-si 52725, Korea; kimkr419@gntech.ac.kr \\ * Correspondence: johnkim@uos.ac.kr; Tel.: +82-2-6490-5609
}

Academic Editors: Geonha Kim and Marc A. Rosen

Received: 31 December 2016; Accepted: 16 March 2017; Published: 19 March 2017

\begin{abstract}
Among many disposal options of animal carcasses due to animal diseases including foot-and-mouth disease (FMD) and avian influenza (AI), on-farm burial has been the most frequently used one in Korea. Animal carcasses generate contaminants such as ammonium-N and chloride. This study aimed at testing biochar (BC) as a permeable reactive barrier (PRB) material in combination with fast growing tree species (Populus euramericana) to mitigate groundwater pollution from animal burial sites. For this, a PRB filled with BC was installed and 400 poplar tree (P. euramericana) seedlings were planted. Tested $\mathrm{BC}$ was obtained from rice husk and its efficiency to mitigate contaminant migration from a burial site of pig carcasses was tested using ammonium-N, chloride, electrical conductivity (EC), and $\mathrm{pH}$ as monitoring parameters. Monitoring wells downstream from the burial site were used. Leachates from a monitoring well, three wells inside the burial site close to PRB and three wells outside the burial site close to PRB were sampled and analyzed for ammonium-N, $\mathrm{Cl}^{-}, \mathrm{EC}$, and $\mathrm{pH}$ for four years from PRB installation. The $\mathrm{pH}, \mathrm{EC}$, and ammonium-N of leachate fluctuated during the test period depending on precipitation. $\mathrm{pH}, \mathrm{EC}$, and ammonium- $\mathrm{N}$ of the leachate samples collected from outside of the burial site close to PRB decreased compared to those from inside of the burial site close to PRB. The concentrations of ammonium-N in the leachate from the monitoring well kept under the threshold value of $10 \mathrm{mg} \cdot \mathrm{L}^{-1}$ for two years from PRB construction. In addition, the growth of poplar plants appeared to be increased via uptaking available $\mathrm{N}$ and $\mathrm{P}$ released from the burial sites. Achieved results suggest that BC PRBs can be used to in situ mitigate contaminant release from buried animal carcasses.
\end{abstract}

Keywords: biochar; contaminants leaching; groundwater quality; livestock disease; on-farm burial; permeable reactive barriers

\section{Introduction}

Foot-and-mouth disease (FMD) and avian influenza (AI) have frequently occurred in the Republic of Korea (Korea). For example, the outbreak of these diseases during 2010 and 2011 occasioned the construction of about 4800 carcass burial sites ( 4583 for FMD and 216 for AI) in rural Korea. At these sites, 7 million poultry and 3.8 million cows and pigs were buried [1-3]. On-farm burial has been the preferred approach for dealing with animal carcass disposal, as it is generally viewed as being 
a relatively quick and affordable method. Conventional alternative methods include composting, rendering, and incineration [4,5]. In addition, the nearest area of remnant farmland has been recommended for burial to effectively prevent the spread of animal diseases in adjacent livestock farms. However, there is a concern regarding the risk of leachate containing high concentrations of contaminants, including ammonium- $\mathrm{N}\left(\mathrm{NH}_{4}{ }^{+}\right)$, nitrate- $\mathrm{N}\left(\mathrm{NO}_{3}{ }^{-}\right)$, chloride $\left(\mathrm{Cl}^{-}\right)$, and fecal pathogens. These contaminants resulted from carcass decomposition can negatively influence the quality of soil and groundwater around the burial sites [5-7].

The literature on contaminant leaching from livestock burial pits is scarce. MacArthur and Milne [8] and Yuan et al. [5] reported on elevated concentrations of ammonium-N in leachates burial sites (at $3294 \mathrm{mg} \cdot \mathrm{L}^{-1}$ and $14,640 \mathrm{mg} \cdot \mathrm{L}^{-1}$, respectively.), compared to the threshold value of $10 \mathrm{mg} \cdot \mathrm{L}^{-1}$ in leachate from monitoring wells. Increased chloride concentrations (about $2600 \mathrm{mg} \cdot \mathrm{L}^{-1}$ ) have been measured as well [5]. Pratt and Fonstad [9] have found that leachate components might vary depending on the type of buried animal carcass: poultry $\left(\mathrm{NH}_{4}{ }^{+} \mathrm{N}\right.$ at $10,400 \mathrm{mg} \cdot \mathrm{L}^{-1}$ and $\mathrm{Cl}^{-}$at $\left.2570 \mathrm{mg} \cdot \mathrm{L}^{-1}\right)$, cattle $\left(\mathrm{NH}_{4}{ }^{+}-\mathrm{N}\right.$ at $14,100 \mathrm{mg} \cdot \mathrm{L}^{-1}$ and $\mathrm{Cl}^{-}$at $\left.2600 \mathrm{mg} \cdot \mathrm{L}^{-1}\right)$, and pig $\left(\mathrm{NH}_{4}{ }^{+}-\mathrm{N}\right.$ at $13,300 \mathrm{mg} \cdot \mathrm{L}^{-1}$ and $\mathrm{Cl}^{-}$at $\left.2380 \mathrm{mg} \cdot \mathrm{L}^{-1}\right)$. Moreover, the extent of groundwater contaminants from carcass burial pits is a function of the scale of the burial site, local soil texture, background water quality, groundwater flow direction, and water table depth [3,4]. Pratt and Fonstad [9] reported that contaminants such as ammonium and chloride were detected in the leachate collected 2 years after carcass burial. They also showed that ammonium concentration in the early stages was the lowest (approximately $5000 \mathrm{mg} \cdot \mathrm{L}^{-1}$ ), whereas it increased steadily for 2 years as animal carcass decomposition progressed. Therefore, countermeasures to mitigate contaminant migration must be applied at the animal carcass burial sites. An innovative approach is the installation of permeable reactive barriers (PRBs) combined with fast-growing tree species, such as Populus spp.

A permeable reactive barrier is a passive and cost-effective technology for in situ remediation of contaminated groundwater [10-12]. PRBs can degrade dissolved contaminants or immobilize them within the reactive wall. The degradation products are ideally less toxic than their reactants [12-14]. A PRB containing a suitable reactive material is possibly a beneficial tool for in situ remediation of subsurface soil contaminated with heavy metal, organic compound, nitrogen compounds, etc. $[12,13,15,16]$. Various materials including zero valent iron, activated carbon, zeolite, and biochar (BC) can be used as suitable reactive material for PRBs [10-16].

Biochar (BC) has recently been introduced as cost-effective adsorbents for organic pollutants, heavy metals, and antibiotics [17-21]. In general, BCs have high cation exchange capacity (CEC) [17-21]. Therefore, BCs could adsorb contaminants in leachate such as heavy metal and ammonium-N through directly binding or adsorbing contaminants [18]. In earlier studies of Yoon and Kim [22] and Kim et al. [23], it was found that rice husk BCs could adsorb high concentrations of ammonium-N. In addition, Kim et al. [23] investigated the potential for remediation of contaminated groundwater using PRBs filled with rice husk $\mathrm{BC}$ and found that they could significantly reduce ammonium-N and $\mathrm{PO}_{4}{ }^{3-}$-P. A potential application of phytoremediation through biodegradation of groundwater contaminants such as excess nutrients or landfill leachates including ammonium- $\mathrm{N}$, nitrate- $\mathrm{N}$, and $\mathrm{PO}_{4}{ }^{3-}$-P has been proposed [24].

Application of phytoremediation to animal carcass burial sites has not been reported yet. However, many researchers reported the use of Populus spp. to soils contaminated with organic contaminants or for remediation of leachate from landfill sites [25-29]. Since most of the animal carcass burial sites in Korea are located at agricultural areas, and sites used for animal carcass burial need to be reused in the future, the application of phytoremediation of soils contaminated with contaminants from animal carcasses is very important from an environmentally-friendly management point of view.

The present study aimed to investigate the effect of PRBs filled with rice husk BCs on in situ remediation of leachate and to explore the effect of phytoremediation on soil properties in a pig carcass burial site over 4 years. 


\section{Materials and Methods}

\subsection{Animal Carcass Disposal Site}

A total of 3147 pigs infected with or suspected of foot-and-mouth disease (FMD) were slaughtered and buried in a pig livestock farm according to the provision of Article 20 of the Act on the Prevention of Livestock Epidemics by the Ministry of Agriculture, Food and Rural Affairs [2]. A burial site located in the central part of Korea was selected, designed, and constructed according to the guideline for environmental management of carcass burial [30] by the Ministry of Environment (MoE), Korea (Figure 1). The area of the burial site, the depth of the pit, and the thickness of the buried animal carcass were $400 \mathrm{~m}^{2}, 4 \mathrm{~m}$, and $1.5 \mathrm{~m}$, respectively. Therefore, the total volume of the animal carcass burial pit was approximately $600 \mathrm{~m}^{3}\left(400 \mathrm{~m}^{2} \times 1.5 \mathrm{~m}\right)$. On completion of the burial site, a monitoring well was installed according to the guidelines of the MoE [30]. Results of the monitoring for the leachate measured at the monitoring well 1 year after burial showed that the ammonium concentration exceeded the threshold value $\left(10 \mathrm{mg} \cdot \mathrm{L}^{-1}\right)$ (Table 1) [30].

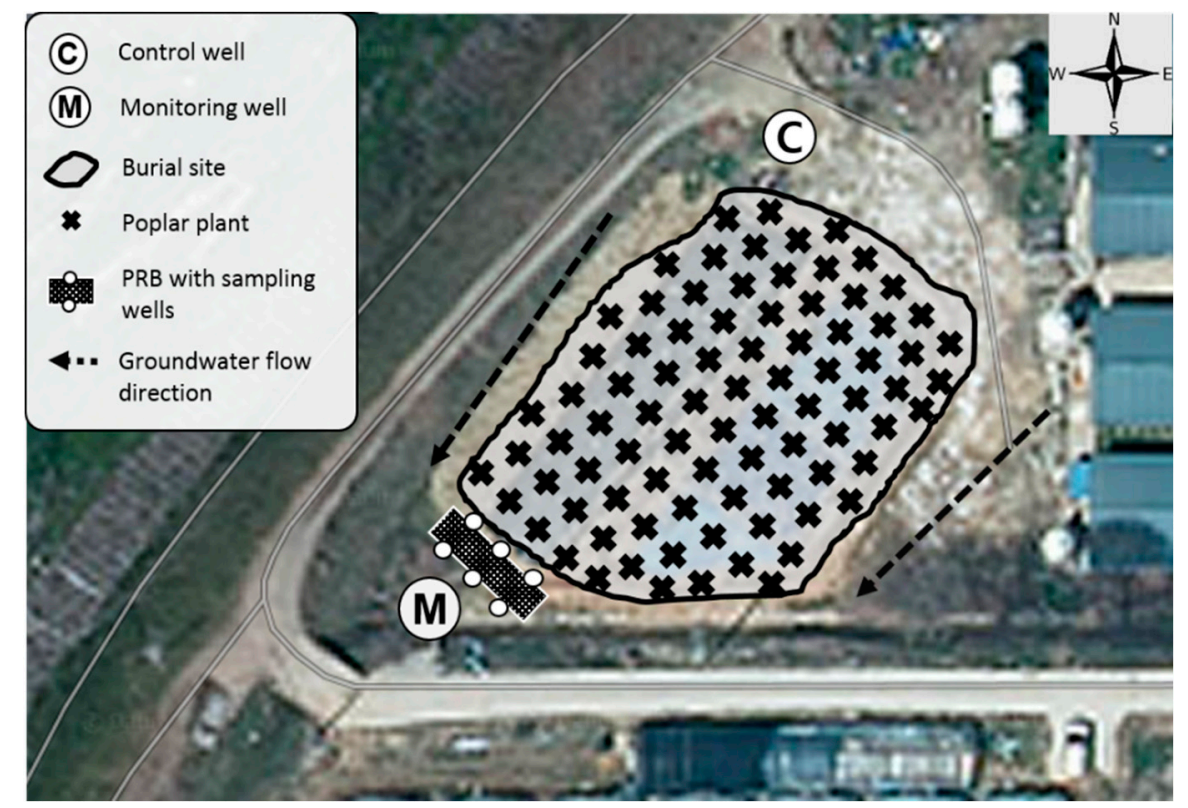

Figure 1. Layout of the leachate sampling wells, permeable reactive barrier (PRB), and planting zone (400 plants) in the burial site.

Table 1. Korean threshold levels for monitoring leachate from burial site [30].

\begin{tabular}{|c|c|}
\hline Threshold Level & Criteria for Judgment \\
\hline Level 1 (high potential) & $\mathrm{NH}_{4}-\mathrm{N} \geq 10 \mathrm{mg} \cdot \mathrm{L}^{-1}$ or $\mathrm{Cl}^{-} \geq 100 \mathrm{mg} \cdot \mathrm{L}^{-1}$ \\
\hline Level 2 (medium potential) & $\begin{array}{c}\mathrm{NH}_{4}-\mathrm{N} \geq 2 \mathrm{mg} \cdot \mathrm{L}^{-1} \text { or } \mathrm{Cl}^{-} \geq 25 \mathrm{mg} \cdot \mathrm{L}^{-1} \text { or Electrical conductivity } \\
(\mathrm{EC}) \geq 800 \mu \mathrm{S} \cdot \mathrm{cm}^{-1}\end{array}$ \\
\hline Level 3 (low potential) & $\begin{array}{c}\mathrm{NH}_{4}-\mathrm{N} \geq 0.1 \mathrm{mg} \cdot \mathrm{L}^{-1} \text { and } \mathrm{Cl}^{-} \geq 4.0 \mathrm{mg} \cdot \mathrm{L}^{-1} \text { and } \\
\left\{\left(\mathrm{Cl}^{-} \text {monitoring well } / \mathrm{Cl}^{-} \text {burial site }\right) \geq 0.05\right\} \text { and } \mathrm{EC} \geq 800 \mu \mathrm{S} \cdot \mathrm{cm}^{-1}\end{array}$ \\
\hline
\end{tabular}

\subsection{Establishment of Permeable Reactive Barrier}

A permeable reactive barrier (PRB) was constructed on the site to reduce the concentrations of contaminants in leachate, particularly ammonium-N. A preliminary study was conducted to determine the existence and direction of flow of shallow groundwater. A PRB was installed at the southwest corner of the carcass burial site based on the results of the preliminary study in March 2013. The dimensions 
of the PRB were $6 \mathrm{~m}$ (length) $\times 1 \mathrm{~m}$ (width) $\times 3 \mathrm{~m}$ (height). The PRB was buried at $2 \mathrm{~m}$ depth from the soil surface. The PRB was filled with rice husk biochar (BC) (DAEWON GSI, Chilgok, Korea) which was produced by slow pyrolysis at about $600{ }^{\circ} \mathrm{C}$ for $10 \mathrm{~h}$. The $\mathrm{pH}, \mathrm{EC}$ (electrical conductivity), and CEC (cation exchange capacity) of the BC used in this study, as analyzed by Kim [31], were 10.2, $0.82 \mathrm{dS} \cdot \mathrm{m}^{-1}$, and $50.35 \mathrm{cmol} \cdot \mathrm{kg}^{-1}$, respectively. The Fourier transform infrared (FTIR) spectra for the BC reported by Kim [31] is shown in Figure 2. The FTIR spectrum of the biochar we used showed significant evidence for alkyl C-O character based on the broad peak centered at $1100 \mathrm{~cm}^{-1}$. The presence of this stretch is consistent with carboxylate functional groups which contribute cation exchange capacity to biochar [32].

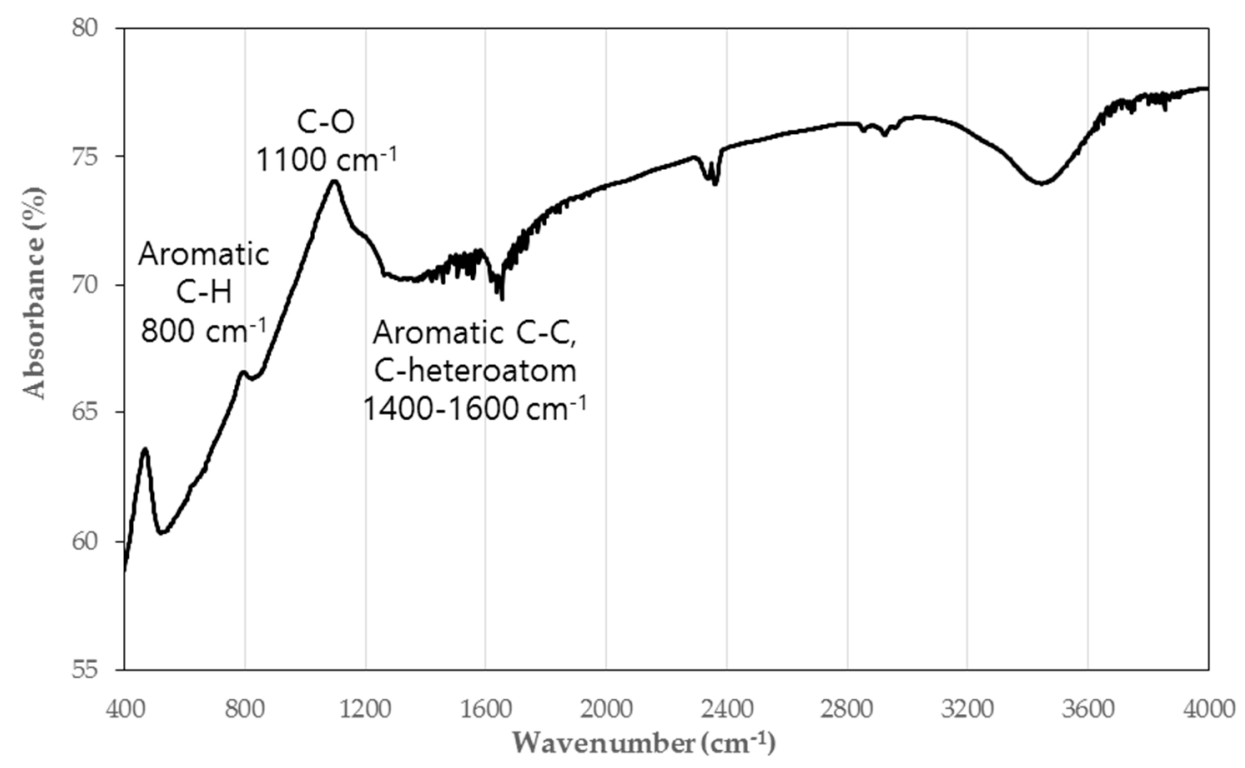

Figure 2. The Fourier transform infrared spectra for rice hull-derived biochar [31].

\subsection{Planting Poplar Trees}

Poplar plants are well-known as fast growing species. They have occasionally been used for biomass production using short-term rotations [33,34]. Based on the results of the preliminary study [35], a poplar tree species (Populus euramericana) was selected to provide vegetation cover on the burial site for this study in order to reduce the releases of contaminants outside of the burial site, particularly soluble $\mathrm{N}$, by plant uptake. This plant species has great capacities in root spreading for nutrient uptake. It can also adapt to multiple environmental conditions [36]. Particularly, this species has been previously used as a solution to remediate various soil and water contaminants $[25,28,29,37]$.

In the present study, four hundred stem cuttings of poplar plant ( $1 \mathrm{~m}$ height) enclosed with a specific guard column were arranged for planting at the burial site. The plant guard column, developed by Seo et al. [35], can aid the ability of plant roots to spread to deeper soil substrate. The guard column does not have harmful effects on root development and plant growth. In the study, poplar trees could be bedded in $1 \mathrm{~m}$ deeper position than the control with the specific guard column (Figure 3). All poplar trees were planted in March 2013. The distance between each tree was one meter. 

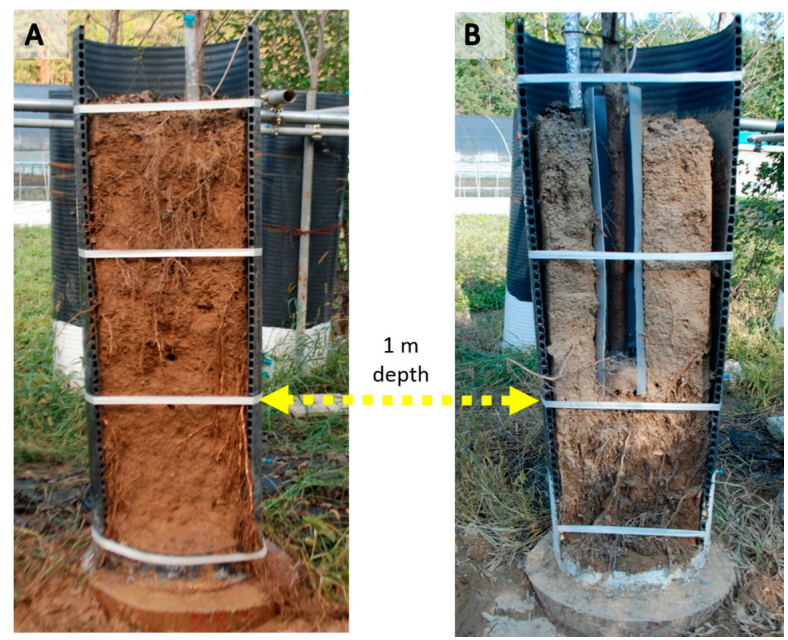

Figure 3. Soil profile of poplar plant rhizosphere. Plant root with a guard column (B) can be positioned one meter deeper than the control (A).

\subsection{Installation of Wells}

For leachate sampling, a total of eight wells ( $3 \mathrm{~m}$ depth) were constructed in situ at the burial site (Figure 1). A control well installed at the upper gradient of the burial site at the opposite direction from groundwater flow (10 $\mathrm{m}$ distance from the border of burial site); three wells were placed inside of the burial site within $0.5 \mathrm{~m}$ of the PRB; three wells were placed outside of the burial site within $0.5 \mathrm{~m}$ of the PRB; and a monitoring well was located at the lowest gradient place (10 m distance from PRB).

\subsection{Soil and Leachate Sampling}

Four months after PRB installation and poplar planting, soil sampling ( $2-3 \mathrm{~m}$ depth) was performed inside and outside of the burial site close to PRB in July 2013. Collected soils were analyzed to determine properties such as $\mathrm{pH}$, electrical conductivity (EC), organic matter $(\mathrm{OM})$, total $\mathrm{N}(\mathrm{TN})$, total $\mathrm{P}(\mathrm{TP})$, ammonium-N, nitrate-N, and $\mathrm{Cl}^{-}$.

Sampling of leachate was conducted over a period of three years to monitor the concentrations of contaminants released from animal carcasses. Samples were taken from all wells in July and December 2013; April and October 2014; June and October 2015; January, April, June, and October 2016. The pH, $\mathrm{EC}$, and ammonium-N of the leachate were determined.

Rhizosphere soils of poplar were collected five times to determine EC, TN, and TP from July 2013 to November 2014. Soils were sampled at three different depths $(40-60,60-80$, and 80-100 cm) ( $n=6$ for each depth). TN and TP in the leaves and stems of poplar trees $(n=6)$ sampled in 2013 and 2014 were also determined. Plant growth was measured in the field and the laboratory in October $2016(n=24)$, including diameter at breast height (DBH), shoot height (SH), and dry weight (DW). The potential of aboveground production (PAP) for four years was estimated using the following Formula (1).

$$
\text { (average DW } \times \text { total plant number)/area }
$$

\subsection{Analytical}

Air-dried soil samples were sieved using a stainless steel sieve $(<2 \mathrm{~mm})$. Soil $\mathrm{pH}$ and EC (1:5W) were measured using a $\mathrm{pH}$ meter (MP 220, Mettler, Zurich, Switzerland) and an EC meter (MC 226, Mellter, Zurich, Switzerland) [38], respectively. For analysis of TN, the air-dried soil was sieved with a $0.5 \mathrm{~mm}$ sieve, digested with concentrated sulfuric acid $\left(\mathrm{H}_{2} \mathrm{SO}_{4}\right)$ and Kjeltabs Se $/ 3,5^{\circledR}$ (3.5 $\mathrm{g} \mathrm{K}_{2} \mathrm{SO}_{4}+3.5 \mathrm{mg} \mathrm{Se}$ ), and determined using a Kjeldahl distiller (Kjeltec 2300, Foss, Hillerød, Denmark) [39]. After digestion with a mixture of concentrated nitric acid $\left(\mathrm{HNO}_{3}\right)$ and perchloric acid 
$\left(\mathrm{HClO}_{4}\right)$ followed by color reaction with ascorbic acid, TP was measured using a ultraviolet-visual spectrophotometer (UV-160A, Shimadzu, Kyoto, Japan) at a wavelength of $470 \mathrm{~nm}$. For ammonium-N, the air-dried soil was extracted with $2 \mathrm{M} \mathrm{KCl}$ solution and steam distilled with $\mathrm{MgO}$ using a Kjeldahl distiller (Kjeltec 2300, Foss, Hillerød, Denmark) [40]. After determining ammonium-N, the soil was steam distilled again with $\mathrm{MgO}$ and Devarda's alloy using a Kjeldahl distiller (Kjeltec 2300, Foss, Hillerød, Denmark) for nitrate-N [40]. $\mathrm{Cl}^{-}$was determined using ion chromatography [41]. Samples of leachate collected from wells were stored at $4{ }^{\circ} \mathrm{C}$ for less than a week prior to analyses. $\mathrm{pH}, \mathrm{EC}$, and ammonium- $\mathrm{N}$ concentration of the leachate samples were determined after filtering with Whatman No. 42 filter paper. Like soil analyses, $\mathrm{pH}$ and EC of leachate samples were measured using $\mathrm{pH}$ and EC meters, respectively. The concentration of ammonium- $\mathrm{N}$ was determined using a Kjeltec auto analyzer (Kjeltec 2300, Foss, Hillerød, Denmark).

Prior to plant harvest, DBH and SH of poplar trees were measured at the site. Five representative poplar trees were selected based on plant growth. The aboveground parts of the five trees were harvested, cut into pieces, and dried at $65^{\circ} \mathrm{C}$ in a drying oven for a week. Samples of dried plants were ground uniformly prior to determination of TN and TP. The plant powder was digested with a mixture of conc. $\mathrm{H}_{2} \mathrm{SO}_{4}$ and $50 \% \mathrm{HClO}_{4}$ at $250{ }^{\circ} \mathrm{C}$ [42]. The resolvent was filtered with Whatman No. 2 filter paper. Total N was determined using Kjeltec auto analyzer (Kjeltec 2300, Foss, Hillerød, Denmark) and Total P was analyzed by vanadate methods [43] with a ultraviolet-visual spectrophotometer (UV-160A, Shimadzu, Kyoto, Japan) at a wavelength of $470 \mathrm{~nm}$.

\subsection{Statistical Analyses}

Minitab 17 (Minitab Inc., State College, PA, USA) was used for all statistical analyses. Differences in rhizosphere soil properties (EC, TN, and TP) in response to soil depth and sampling time were assessed with a one-way analysis of variance (ANOVA) using a Fisher's Least Significant Difference (LSD) test $(n=6, p<0.05)$. Differences in $\mathrm{pH}, \mathrm{EC}$, and ammonium-N of leachate samples in relation to the location of the wells were also assessed (LSD, $n=3, p<0.05$ ). To determine effects of rainfall on leachate composition, a correlation coefficient $(r)$ was calculated to estimate the relationship between precipitation and leachate properties such as $\mathrm{pH}, \mathrm{EC}$, and ammonium- $\mathrm{N}$ concentration.

\section{Results}

\subsection{Properties of the Soils}

Four months after PRB establishment, substantial differences in soil properties between the soil inside of the burial site close to PRB and those outside of the burial site close to PRB were found (Table 2). Compared to soil properties near PRB inside of the burial site, higher soil $\mathrm{pH}$ but lower EC, $\mathrm{OM}, \mathrm{TN}, \mathrm{TP}$, and $\mathrm{Cl}^{-}$were detected in soil near PRB outside of the burial site. In terms of soluble $\mathrm{N}$, ammonium-N in the soil near PRB inside of the burial site $\left(170 \mathrm{mg} \cdot \mathrm{kg}^{-1}\right)$ was five times higher than that in the soil near PRB outside of the burial site $\left(36 \mathrm{mg} \cdot \mathrm{kg}^{-1}\right)$. However, there was no variation in nitrate- $\mathrm{N}$ concentrations between those soils. The $\mathrm{pH}$ of the soil around the monitoring well was higher than that around the PRB, and nitrates were not measured.

Table 2. Variation of soil chemical properties depending on location relative to burial site and permeable reactive barrier (PRB) after 4 months of the PRB installation (monitoring well is located five meters down from the PRB).

\begin{tabular}{|c|c|c|c|c|c|c|c|c|}
\hline Location of Soil Samples & $\underset{(1: 5 W)}{\mathrm{pH}}$ & $\begin{array}{c}\mathrm{EC} \\
\left(\mathrm{dS} \cdot \mathrm{m}^{-1}\right)\end{array}$ & $\begin{array}{l}\text { OM } \\
(\%)\end{array}$ & $\begin{array}{l}\mathrm{T}-\mathrm{N} \\
(\%)\end{array}$ & $\begin{array}{l}\text { T-P } \\
(\%)\end{array}$ & $\begin{array}{c}\mathrm{NH}_{4}-\mathrm{N} \\
\left(\mathrm{mg} \cdot \mathrm{kg}^{-1}\right)\end{array}$ & $\begin{array}{c}\mathrm{NO}_{3}-\mathrm{N} \\
\left(\mathrm{mg} \cdot \mathrm{kg}^{-1}\right)\end{array}$ & $\begin{array}{c}\mathrm{Cl}^{-} \\
\left(\mathrm{mg} \cdot \mathrm{kg}^{-1}\right)\end{array}$ \\
\hline The soil near PRB inside of the burial site & 4.9 & 0.22 & 12.7 & 0.14 & 651 & 171 & 22.1 & 4.84 \\
\hline The soil near PRB outside of the burial site & 5.5 & 0.06 & 0.61 & 0.03 & 299 & 35.8 & 22.1 & 2.75 \\
\hline The soil near monitoring well & 6.3 & 0.08 & 0.53 & 0.03 & 243 & 38.6 & N.M. ${ }^{1}$ & 4.24 \\
\hline
\end{tabular}




\subsection{Leachate Properties}

During monitoring from June 2013 to October 2016, leachate properties demonstrated observable changes: $\mathrm{pH}$ increased from 6.01 to 7.15 ; EC increased from 0.12 to $0.31 \mathrm{dS} \cdot \mathrm{m}^{-1}$, and ammonium-N increased from 11 to $41 \mathrm{mg} \cdot \mathrm{L}^{-1}$ (Figure 4). EC and ammonium-N in the leachate collected from the wells inside of the burial site close to the PRB appeared to be lower than those collected from the wells outside of the burial site close to the PRB. The leachate sampled in June 2015 showed sighnificant differences (LSD, $p<0.05$ ). Among leachates collected from the wells outside of the burial site close to the PRB over the monitoring period, the highest concentrations of $\mathrm{pH}, \mathrm{EC}$, and ammonium-N were detected in samples collected in June 2016, whereas the lowest concentrations were detected in the samples collected in April 2014 and June 2015. Similar fluctuation was shown between leachate properties of the control and monitoring wells for 3 years. However, there were substantial increases in $\mathrm{pH}$ and ammonium- $\mathrm{N}$ concentration in the leachate samples collected from the monitoring well in October 2015.
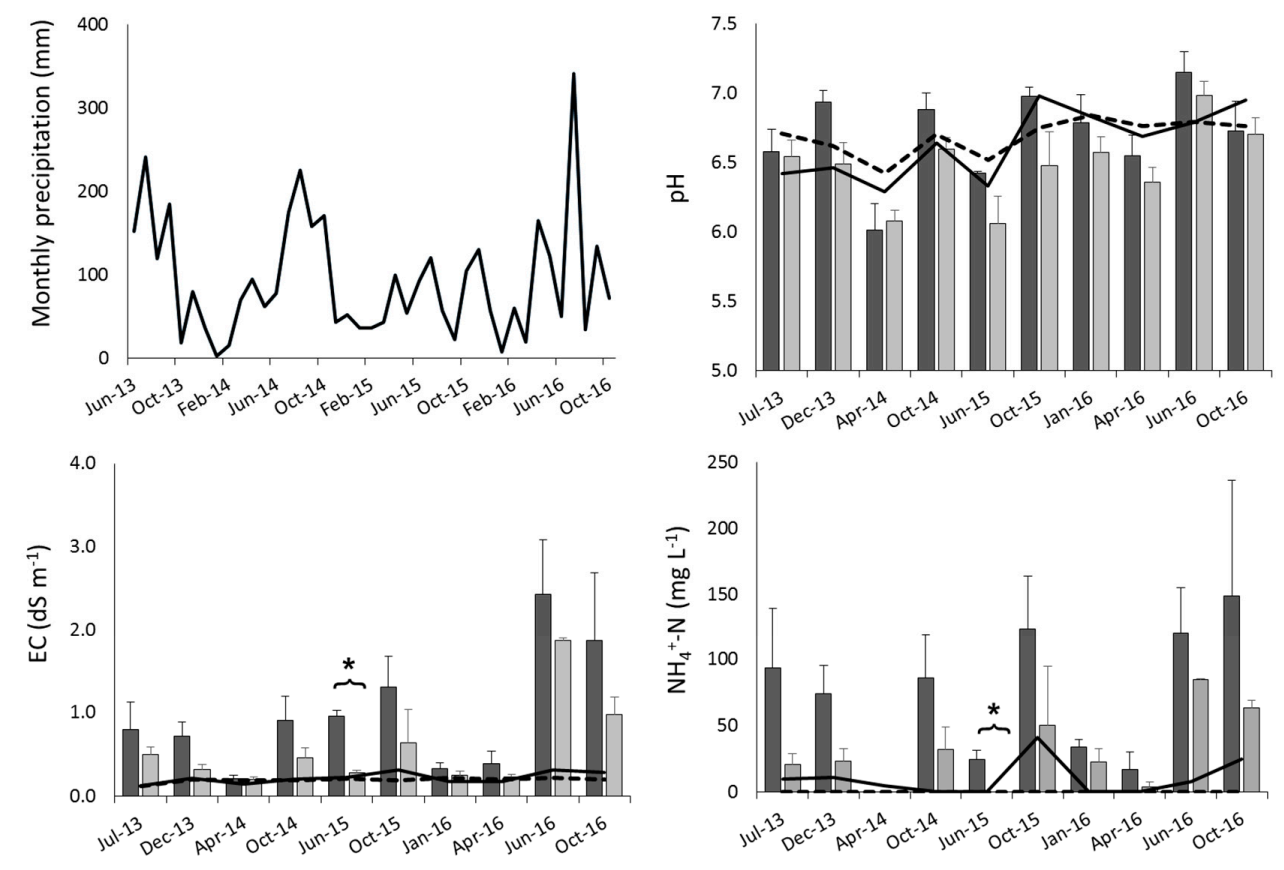

$\square$ Wells inside of the burial site near PRB

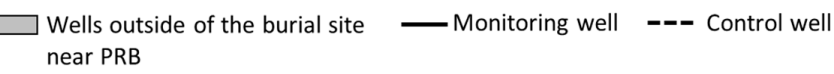

Figure 4. Monthly precipitation, $\mathrm{pH}, \mathrm{EC}$, and $\mathrm{NH}_{4}{ }^{+}-\mathrm{N}$ of leachate samples collected from wells at the burial site. Asterisk $\left(^{*}\right)$ indicates significant difference in properties of the leachates from the wells near PRB $(n=6$; LSD, $p<0.05)$.

\subsection{Rhizosphere Soil Properties}

Properties of rhizosphere soil used for poplar trees were different depending on soil depth and sampling time (Figure 5). EC of the soil collected from 80 to $100 \mathrm{~cm}$ was significantly $(p<0.05)$ higher than that of the shallower soils of $40-60$ or $60-80 \mathrm{~cm}$ collected in July 2013 . The EC was substantially $(p<0.05)$ decreased in March 2014. Total $\mathrm{N}$ contents in soils were gradually decreased across the whole soil profile from the middle of 2013 to the end of 2014. Significant $(p<0.05)$ reductions in total $\mathrm{N}$ contents were found at soil with depths of $40-60$ and $60-80 \mathrm{~cm}$ over the study period. Total $\mathrm{P}$ contents were marginally decreased in March 2014 in the deepest soil $(80-100 \mathrm{~cm})$. At that sampling date, the concentrations of TP were gradually increased in shallower soils. The concentrations of TP in shallow soils were higher than those in the deepest soils. 

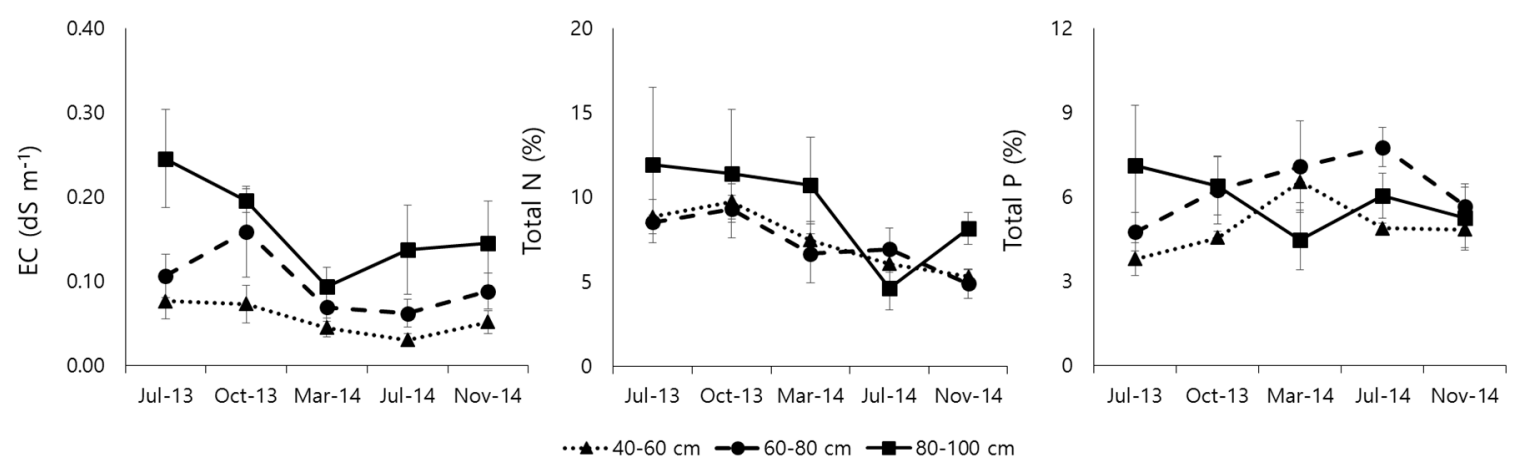

Figure 5. Changes in EC, Total N, and Total P content in soils used for poplar cultivation at three depths collected from July 2013 to November $2014(n=6)$.

\subsection{Plant Growth}

All poplar trees grew very well at the burial site. Plant shoot height (SH) was increased from $1 \mathrm{~m}$ to $7.61 \mathrm{~m}$ during the study period (Table 3). DBH and dry weight (DW) of each plant also increased to about $22 \mathrm{~cm}$ and $10 \mathrm{~kg}$, respectively. The potential of plant production in four years was estimated at approximately 85 ton $\cdot \mathrm{ha}^{-1}$. No significant $(p>0.05)$ difference in TN or TP of poplar leaves was found between samples collected in 2013 and 2014. Plant stems contained $5.2 \mathrm{~g} \cdot \mathrm{kg}^{-1}$ of TN and $1.2 \mathrm{~g} \cdot \mathrm{kg}^{-1}$ of TP, respectively (Table 4).

Table 3. Measurements of plant growth indicators such as diameter at breast height (DBH), shoot height (SH), dry weight (DW), and potential of aboveground production (PAP) (value in parenthesis represents standard error of the mean, $n=24)$.

\begin{tabular}{cccc}
\hline DBH $(\mathrm{cm})$ & SH $(\mathrm{cm})$ & DW (kg/Plant) & PAP (ton DW/ha/4 Years) \\
\hline $22.1(4.1)$ & $761.3(50.4)$ & $10.7(4.1)$ & 85.3 \\
\hline
\end{tabular}

Table 4. Total N and P concentrations in leaves and shoots of poplar plants in 2013 and 2014 (value in parenthesis represents standard error of the mean, $n=5$; same letters in superscript indicate no significant difference, LSD, $p<0.05$ ).

\begin{tabular}{ccccc}
\hline \multirow{2}{*}{ Sampling Year } & \multicolumn{2}{c}{ Total $\mathbf{N}\left(\mathbf{g} \cdot \mathbf{k g}^{-1}\right)$} & \multicolumn{2}{c}{ Total $\mathbf{P}\left(\mathbf{g} \cdot \mathbf{k g}^{-\mathbf{1}}\right)$} \\
\cline { 2 - 5 } & Leaf & Stem & Leaf & Stem \\
\hline 2013 & $22.6(1.0)^{\mathrm{a}}$ & - & $0.5(0.1)^{\mathrm{a}}$ & - \\
2014 & $23.7(1.1)^{\mathrm{a}}$ & $5.2(1.1)$ & $0.4(<0.1)^{\mathrm{a}}$ & $1.2(0.1)$ \\
\hline
\end{tabular}

\section{Discussion}

\subsection{Impacts of PRB on Soil Properties}

The PRB filled with rice husk BCs seemed to influence the flow of contaminants from the carcass burial site in this study. The EC and concentrations of TP, TN, ammonium-N, and chloride were considerably different between soils collected inside and outside of the burial site close to the PRB (73\%, 54\%, 79\%, 79\%, and $42 \%$ higher concentrations were detected in the soil collected from inside of the burial site close to the PRB, respectively). The differences in contaminant concentrations may be due to the $B C$ containing high anion exchange capacity (AEC) and CEC, thereby possibly allowing the $\mathrm{BC}$ to adsorb the contaminants in soil $[18,44]$. Kim et al. [23] have also found that soils collected from inside of the burial site close to a PRB had an increased amount of contaminants such as TN, $\mathrm{TP}$, and K compared to the soil collected from outside of the burial site close to the PRB. However, differences in soil OM appeared not to be associated with the presence of PRB. It was likely due to the 
fact that surface soils covering the carcasses had significantly more amounts of OM than subsurface soils outside of the burial site. Lime treatment used to eliminate harmful pathogens result in increased $\mathrm{pH}$ of the soil from the burial site. However, the $\mathrm{pH}$ of the burial pit soil was lower than surrounding soils. Such a decrease in $\mathrm{pH}$ might be due to bacterial fermentation products via metabolic processes which could convert sugar to acids, particularly under aerobic conditions $[3,5]$.

\subsection{Removal of Leachate Contaminants by PRB}

Overall, the $\mathrm{pH}, \mathrm{EC}$, and ammonium- $\mathrm{N}$ concentrations of the groundwater changed with the presence of the PRB. The PRB played a role in the elimination of contaminants in leachate by adsorption on the surface of biochar. Unlike soil $\mathrm{pH}$, lime addition to the burial site might have contributed to a marginal increase of leachate $\mathrm{pH}$ (near neutral) of wells inside of the burial site close to the PRB [9]. Additionally, high concentrations of calcium dissolved from the decomposition of the carcasses might have raised the $\mathrm{pH}$ of the leachate [3]. Particularly, leachate properties seemed to depend on monitoring season and monthly precipitation in the study area. Winter and spring seasons, representing low rainfall periods, were less likely to influence the flow of groundwater contaminants. In contrast, during and after summer, EC and ammonium-N concentrations in the leachate were significantly increased. The increase in contaminant release might be associated with increased ambient temperature which is a determinant of decomposition rates [45]. The summer temperature of over $30^{\circ} \mathrm{C}$ at the burial site for this study might have facilitated the activities of microorganisms and carrion entomofauna, thus stimulating the process of carcass decomposition [46]. Moreover, precipitation in rainy season is likely to increase $\mathrm{N}$ leaching from the burial site [46]. A significant correlation between precipitation and ammonium- $\mathrm{N}$ concentration in leachate sampled from the wells inside of the burial site close to the PRB $(r=0.764, p=0.01)$ was found (Figure 6$)$. Although EC appeared to show similar patterns over the study period, no significant $(p>0.05)$ correlation between EC and precipitation was found.

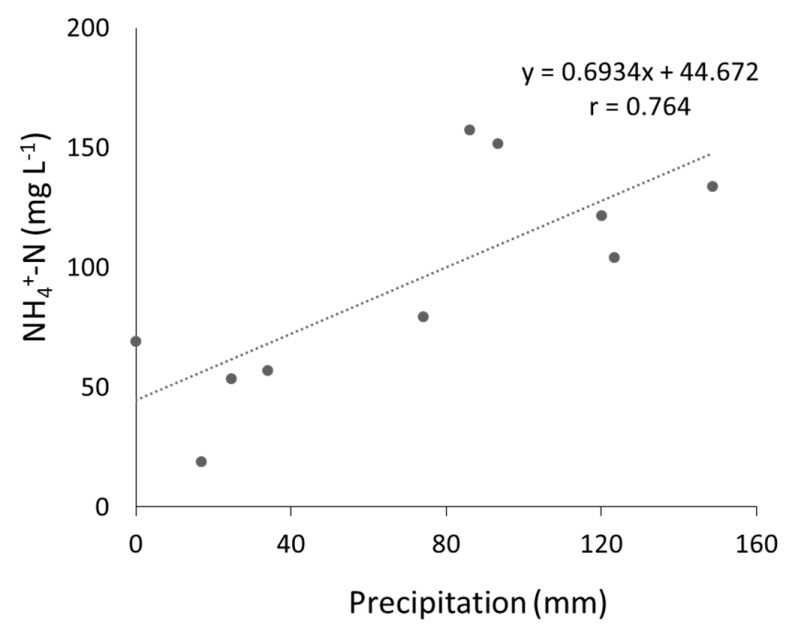

Figure 6. Correlation between precipitation and ammonium-N concentration.

\subsection{Phytoremediation Effects}

Populus spp. generally has the capacity to develop more fine roots that facilitate the uptake of water and nutrients. This also benefits the microhabitats of the rhizosphere, thereby enhancing soil quality [47]. In this study, the rhizosphere of poplar with a specific guard column was formed at soil depth of approximately $1 \mathrm{~m}$. As a result, relatively more reductions in EC, TN, and TP concentrations in soil depth of 80-100 cm were found compared to those of shallower soils. Therefore, carcass leachate containing available nutrients such as ammonium, nitrate, and phosphate appeared to enhance the growth of poplar plants in the present study. Due to spillover nutrients, aboveground growth rate of 
poplar plants in this study $\left(21.3 \mathrm{ton} \cdot \mathrm{ha}^{-1} \cdot \mathrm{yr}^{-1}\right)$ in this study was relatively larger than that of other populous spp. (from 6.5 to $13.6 \mathrm{ton} \cdot \mathrm{ha}^{-1} \cdot \mathrm{yr}^{-1}$ ) reported in other studies [48-51].

\subsection{Improving Removal Efficiency}

In this study, leachate sampling was not implemented from the center of burial pits due to hygienic reasons. However, when considering properties of the leachate collected from the wells inside of the burial site close to the PRB ( $1 \mathrm{~m}$ distance from the burial pits), the pig burial site of this study seemed to release relatively lower concentrations of contaminants, particularly ammonium-N, compared to other in situ burial sites: 9,300 to $13,800 \mathrm{mg} \cdot \mathrm{L}^{-1}$ [52] and 2,833 $\mathrm{mg} \cdot \mathrm{L}^{-1}$ [53] in Korea; $12,600 \mathrm{mg} \cdot \mathrm{L}^{-1}$ in Canada [9]; $870 \mathrm{mg} \cdot \mathrm{L}^{-1}$ in UK [54]. The difference in contaminant concentrations between burial sites might have been affected by carcass burial density and burial depth because the amount of leachate depends on burial density and volume. Moreover, the type of animals, local climate, and soil properties such as mineralogy, permeability, and organic $C$ status influence the difference in contaminant concentrations $[3,4,9,55]$.

However, over the period of leachate monitoring using monitoring wells, EC and ammonium-N concentrations gradually increased, exceeding $0.8 \mathrm{dS} \cdot \mathrm{m}^{-1}$ and $10 \mathrm{mg} \cdot \mathrm{kg}^{-1}$ of their respective threshold values (see Table 1) [30]. Although establishments of the PRB and phytoremediation apparently reduced contaminants leaching in the current study, more effective technologies need to be developed in order to better address the exponential growth of recent outbreaks of FMD and AI in Korea. For example, smaller sized particles of reactive medium in PRBs could enhance the capacity of ion adsorption by increasing the surface area of the media. Thus, the flow of contaminants could be mediated with the modified internal pore structure in the media of PRBs [18,56]. Kizito et al. [57] have found that ammonium- $\mathrm{N}$ adsorption capacity of a rice husk biochar is increased when its particle size is decreased. In addition, decreased hydraulic conductivity (HC) of smaller sized biochars may extend the contacting period with contaminants [58]. The biochar HC used in this study was large $\left(2 \times 10^{-3} \mathrm{~m} \cdot \mathrm{s}^{-1}\right)$. If smaller sized rice husk BCs were used in this study as reactive media for the PRB, it might have contributed more effectively to in situ remediation of contaminants.

\section{Conclusions}

Although on-farm burial of animal carcasses has potential risks of contaminants leaching into the surrounding environment, resulting in the degradation of soil and groundwater quality, it is a preferred and the only practical approach in Korea so far. A permeable reactive barrier with rice husk biochar used in this study reduced contaminants leaching from an animal carcass burial site, particularly ammonium-N. In terms of in situ phytoremediation, poplar plants also appeared to reduce EC and concentrations of ammonium-N by contaminant uptake. Despite some limitations, the application of phytoremediation by woody plants and PRB could be one of the attractive options for environmentally-friendly and sustainable management of animal carcass burial sites constructed in agricultural areas.

Acknowledgments: This subject is supported by the Korean Ministry of Environment as the GAIA Project (2012-00056-0004).

Author Contributions: Jung-Hwan Yoon, Young-Nam Kim, Dong-Chun Shin, Kwon-Rae Kim, and Kye-Hoon Kim designed and developed the idea of the paper; Jung-Hwan Yoon and Young-Nam Kim analyzed the data; and Kye-Hoon Kim reviewed related previous research. All authors wrote and reviewed the manuscript.

Conflicts of Interest: The authors have no conflict of interest to declare.

\section{References}

1. Cho, H.S.; Kim, G.H. Needs of Biosecurity and Protocols for the Environmental Management of Carcasses Burial. J. Korean Soc. Water Environ. 2012, 28, 305-312.

2. Kim, M.H.; Kim, G. Analysis of environmental impacts of burial sites. J. Mater. Cycles Waste Manag. 2015, 17, 1-11. [CrossRef] 
3. Choi, N.C.; Choi, E.J.; Kim, B.J.; Park, J.A.; Kim, S.B.; Park, C.Y. Characterization of water quality and the aerobic bacterial population in leachate derived from animal carcass disposal. J. Eng. Geol. 2013, 23, 37-46. [CrossRef]

4. Gwyther, C.L.; Williams, A.P.; Golyshin, P.N.; Edwards-Jones, G.; Jones, D.L. The environmental and biosecurity characteristics of livestock carcass disposal methods: A review. Waste Manag. 2011, 31, 767-778. [CrossRef] [PubMed]

5. Yuan, Q.; Snow, D.D.; Bartelt-Hunt, S.L. Potential water quality impacts originating from land burial of cattle carcasses. Sci. Total Environ. 2013, 456-457, 246-253. [CrossRef] [PubMed]

6. Kang, M.A.; Kim, M.S.; Choi, B.W.; Sohn, H.Y. Organic matter analysis and physicochemical properties of leachate from a foot-and-mouth disease landfill site. Microbiol. Biotechnol. Lett. 2012, 40, 128-134. [CrossRef]

7. Scudamore, J.M.; Trevelyan, G.M.; Tas, M.V.; Varley, E.M.; Hickman, G.A.W. Carcass disposal: Lessons from Great Britain following the foot and mouth disease outbreaks of 2001. Rev. Sci. Tech. (Int. Off. Epizoot.) 2002, 21, 775-787. [CrossRef]

8. MacArthur, A.J.; Milne, J.C. Leachate characteristics and management requirements arising from the foot \& mouth operations in Scotland. In Proceedings of the Waste 2002 Integrated Waste Management and Pollution Control: Research, Policy, and Practice, Stratford-upon-Avon, UK, 24-26 September 2002; pp. 305-314.

9. Pratt, D.L.; Fonstad, T.A. Livestock mortalities burial leachate chemistry after two years of decomposition. In Proceedings of the American Society of Agricultural and Biological Engineers, Reno, Nevada, USA, 21-24 June 2009.

10. Cundy, A.B.; Hopkinson, L.; Whitby, R.L. Use of iron-based technologies in contaminated land and groundwater remediation: A review. Sci. Total Environ. 2008, 400, 42-51. [CrossRef] [PubMed]

11. Scherer, M.M.; Richter, S.; Valentine, R.L.; Alvarez, P.J. Chemistry and microbiology of permeable reactive barriers for in situ groundwater clean up. Crit. Rev. Environ. Sci. Technol. 2000, 30, 363-411. [CrossRef]

12. Thiruvenkatachari, R.; Vigneswaran, S.; Naidu, R. Permeable reactive barrier for groundwater remediation. J. Ind. Eng. Chem. 2008, 14, 145-156. [CrossRef]

13. Patterson, B.M.; Grassi, M.E.; Robertson, B.S.; Davis, G.B.; Smith, A.J.; McKinley, A.J. Use of polymer mats in series for Sequential Reactive Barrier Remediation of Ammonium-contaminated Groundwater: Field evaluation. Environ. Sci. Technol. 2004, 38, 6846-6854. [CrossRef] [PubMed]

14. Carniato, L.; Schoups, G.; Seuntjens, P.; Van Nooten, T.; Simons, Q.; Bastiaens, L. Predicting longevity of iron permeable reactive barriers using multiple iron deactivation models. J. Contam. Hydrol. 2012, 142, 93-108. [CrossRef] [PubMed]

15. Bastiaens, L.; Dries, J.; Vos, J.; Simons, Q.; Smet, M.D.; Diels, L. 2 New Developments in PRB Technology-Comparison of different multibarrier concepts designed for treatment of groundwater containing mixed pollutants. IAHS Publ. Ser. Proc. Rep. 2005, 298, 45-51.

16. Park, J.B.; Lee, S.H.; Lee, J.W.; Lee, C.Y. Lab scale experiments for permeable reactive barriers against contaminated groundwater with ammonium and heavy metals using clinoptilolite (01-29B). J. Hazard. Mater. 2002, 95, 65-79. [CrossRef]

17. Beesley, L.; Moreno-Jiménez, E.; Gomez-Eyles, J.L.; Harris, E.; Robinson, B.; Sizmur, T. A review of biochar's potential role in the remediation, revegetation and restoration of contaminated soils. Environ. Pollut. 2011, 159, 3269-3282. [CrossRef] [PubMed]

18. Major, J.; Steiner, C.; Downie, A.; Lehmann, J. Biochar effects on nutrient leaching. In Biochar for Environmental Management: Science and Technology; Lehmann, J., Joseph, S., Eds.; Earthscan: London, UK, 2009; pp. 271-287.

19. Srinivasan, P.; Sarmah, A.K. Characterisation of agricultural waste-derived biochars and their sorption potential for sulfamethoxazole in pasture soil: a spectroscopic investigation. Sci. Total Environ. 2015, 502, 471-480. [CrossRef] [PubMed]

20. Wang, S.; Gao, B.; Zimmerman, A.R.; Li, Y.; Ma, L.; Harris, W.G.; Migliaccio, K.W. Physicochemical and sorptive properties of biochars derived from woody and herbaceous biomass. Chemosphere 2015, 134, $257-262$. [CrossRef] [PubMed]

21. Zhang, X.; Wang, H.; He, L.; Lu, K.; Sarmah, A.; Li, J.; Bolan, N.S.; Pei, J.; Huang, H. Using biochar for remediation of soils contaminated with heavy metals and organic pollutants. Environ. Sci. Pollut. Res. 2013, 20, 8472-8483. [CrossRef] [PubMed] 
22. Yoon, J.H.; Kim, K.H. Application of biochar from organic wastes for remediation of leachate from animal carcass. In Proceedings of the Korean Society of Soil Sciences and Fertilizer, Muju, Korea, 20-21 October 2016; p. 318.

23. Kim, G.H.; Chowdhury, S.; Bolan, N. Assessing the efficiency of permeable reactive barrier to reduce the groundwater contamination from carcass burial. In Proceedings of the IWA World Water Congress \& Exhibition, Brisbane, Australia, 9-14 October 2016.

24. Schnoor, J.L.; Light, L.A.; McCutcheon, S.C.; Wolfe, N.L.; Carreia, L.H. Phytoremediation of organic and nutrient contaminants. Environ. Sci. Technol. 1995, 29, 318A-323A. [CrossRef] [PubMed]

25. Lee, E.D.; Woo, S.Y.; Yeo, J.K.; Koo, Y.B.; Chun, S.H. Sapflow change and growth response of poplar species under swine wastewater irrigation. J. Korean For. Soc. 2009, 98, 740-747.

26. Justin, M.Z.; Pajk, N.; Zupanc, V.; Zupančič, M. Phytoremediation of landfill leachate and compost wastewater by irrigation of Populus and Salix: biomass and growth response. Waste Manag. 2010, 30, 1032-1042. [CrossRef] [PubMed]

27. Zalesny, J.A.; Zalesny, R.S.; Coyle, D.R.; Hall, R.B. Growth and biomass of Populus irrigated with landfill leachate. For. Ecol. Manag. 2007, 248, 143-152. [CrossRef]

28. Dix, M.E.; Klopfenstein, N.B.; Zhang, J.W.; Workman, S.W.; Kim, M.S. Potential use of Populus for phytoremediation of environmental pollution in riparian zones. In Micropropagation, Genetic Engineering, and Molecular Biology of Populus; Klopfenstein, N.B., Chun, Y.W., Kim, M.S., Ahuja, M.A., Dillon, M.C., Carman, R.C., Eskew, L.G., Eds.; Rochy Mountain Forest and Range Experiment Station: Fort Collins, CO, USA, 1997; pp. 206-211.

29. Licht, L.A.; Isebrands, J.G. Linking phytoremediated pollutant removal to biomass economic opportunities. Biomass Bioenergy 2006, 28, 203-218. [CrossRef]

30. Ministry of Environment (MOE). Environment Management Guideline of Carcass Burial Sites; Ministry of Environment: Seoul, Korea, 2012.

31. Kim, H.S. Rice Hull-Derived Biochar as a Stabilizer for Heavy Metal, an Ameliorant for Reclaimed Tidal Soil and a Material for Growing Substrate. Ph.D. Thesis, University of Seoul, Seoul, Korea, February 2013.

32. Liang, B.; Lehmann, J.; Solomon, D.; Kinyangi, J.; Grossman, J.; O’Neill, B.; Skjemstad, J.O.; Thies, J.; Luizão, F.J.; Petersen, J.; et al. Black carbon increases cation exchange capacity in soils. Soil Sci. Soc. Am. J. 2006, 70, 1719-1730. [CrossRef]

33. Dickmann, D.I.; Isebrands, J.G.; Eckenwalder, J.E.; Richardson, J. Poplar Culture in North America; NCR-CNRC; NCR Research Press: Ottawa, ON, Canada, 2001; p. 397.

34. Gordon, J.C.; Promnitz, L.C. Photosynthetic and enzymatic criteria for the early selection of fast-growing Populus clones. In Tree Physiology and Yield Improvement; Cannell, M.G.R., Last, F.T., Eds.; Academic Press: New York, NY, USA, 1976; pp. 79-97.

35. Seo, B.H.; Kim, H.S.; Kuppusamy, S.; Kim, K.H.; Kim, K.R. Enhanced Nitrogen and Phosphorus Removal by Woody Plants with Deep-Planting Technique for the Potential Environmental Management of Carcass Burial Sites. Sustainability 2017, 9, 155. [CrossRef]

36. Heilman, P.E.; Fu-Guang, X. Influence of nitrogen on growth and productivity of short-rotation Populus trichocarpa $\times$ Populus deltoides hybrid. Can. J. For. Res. 1993, 23, 1863-1869. [CrossRef]

37. Yeo, J.K.; Koo, Y.B.; Kim, H.C.; Shin, H.N.; Lee, E.D. Removal of swine wastewater by evapotranspiration at poplar plantation and growth characteristics of poplar clones. Korean Soc. Waste Manag. 2010, 27, 226-233.

38. Thomas, G.W. Soil pH and soil acidity. In Methods of Soil Analysis Part 3: Chemical Methods, 2nd ed.; Sparks, D.L., Page, A.L., Helmke, P.A., Loeppert, R.H., Soltanpour, P.N., Tabatabai, M.A., Johnston, C.T., Sumner, M.E., Eds.; Soil Science Society of America and American Society of Agronomy: Madison, WI, USA, 1996; pp. 475-490.

39. Bremner, J.M. Nitrogen-total. Methods of soil analysis. In Methods of Soil Analysis Part 3: Chemical Methods, 2nd ed.; Sparks, D.L., Page, A.L., Helmke, P.A., Loeppert, R.H., Soltanpour, P.N., Tabatabai, M.A., Johnston, C.T., Sumner, M.E., Eds.; Soil Science Society of America and American Society of Agronomy: Madison, WI, USA, 1996; pp. 1085-1121.

40. Mulvaney, R.L. Nitrogen-Inorganic forms. In Methods of Soil Analysis Part 3: Chemical Methods, 2nd ed.; Sparks, D.L., Page, A.L., Helmke, P.A., Loeppert, R.H., Soltanpour, P.N., Tabatabai, M.A., Johnston, C.T., Sumner, M.E., Eds.; Soil Science Society of America and American Society of Agronomy: Madison, WI, USA, 1996; pp. 869-920. 
41. Frankenberger, W.T.; Tabatabai, M.A.; Adriano, D.C.; Doner, H.E. Bromine, chlorine, \& fluorine. In Methods of Soil Analysis Part 3: Chemical Methods, 2nd ed.; Sparks, D.L., Page, A.L., Helmke, P.A., Loeppert, R.H., Soltanpour, P.N., Tabatabai, M.A., Johnston, C.T., Sumner, M.E., Eds.; Soil Science Society of America and American Society of Agronomy: Madison, WI, USA, 1996; pp. 833-867.

42. Cresser, M.S.; Parsons, J.W. Sulphuric-Perchloric acid digestion of plant material for the determination of nitrogen, phosphorus, potassium, calcium and magnesium. Anal. Chim. Acta 1979, 109, 431-436. [CrossRef]

43. Kuo, S. Phosphorus. In Methods of Soil Analysis Part 3: Chemical Methods, 2nd ed.; Sparks, D.L., Page, A.L., Helmke, P.A., Loeppert, R.H., Soltanpour, P.N., Tabatabai, M.A., Johnston, C.T., Sumner, M.E., Eds.; Soil Science Society of America and American Society of Agronomy: Madison, WI, USA, 1996; pp. 869-920.

44. Lawrinenko, M.; Laird, D.A. Anion exchange capacity of biochar. Green Chem. 2015, 17, 4628-4636. [CrossRef]

45. Sharanowski, B.J.; Walker, E.G.; Anderson, G.S. Insect succession and decomposition patterns on shaded and sunlit carrion in Saskatchewan in three different season. Forensic Sci. Int. 2008, 179, 219-240. [CrossRef] [PubMed]

46. Linhares, A.X.; de Carvalho, L.M.L. Seasonality of insect succession and pig carcass decomposition in a natural forest area in southeastern Brazil. J. Forensic Sci. 2001, 46, 604-608.

47. Westphal, L.M.; Isebrands, J.G. Phytoremediation of Chicago's brown fields: consideration of ecological approaches and social issues. In Proceedings of the Brownfields Conference, Chicago, IL, USA, 20 August 2001.

48. Armstrong, A.; Johns, C.; Tubby, I. Effects of spacing and cutting cycle on the yield of poplar grown as an energy crop. Biomass Bioenergy 1999, 17, 305-314. [CrossRef]

49. Bowersox, T.W.; Ward, W.W. Growth and yield of close-spaced young hybrid poplars. For. Sci. 1976, 22, 449-454.

50. Laureysens, I.; Bogaert, J.; Blust, R.; Ceulemans, R. Biomass production of 17 poplar clones in a short-rotation coppice culture on a waste disposal site and its relation to soil haracteristics. For. Ecol. Manag. 2004, 187, 295-309. [CrossRef]

51. Wittmer, R.F.; Immel, M.J. A comparison of five tree species for intensive fiber production. For. Ecol. Manag. 1997, 1, 249-254. [CrossRef]

52. Kim, D.W.; Yu, S.H.; Chang, S.W.; Lee, J.A. Ecotoxicty assessment of leachate from disposal site for foot-and-mouth disease carcasses. J. Korean Geo-Environ. Soc. 2014, 15, 5-11.

53. Korea Environment Corporation (KECO). A Study on the Environmental Assessment of Surrounding Area of AI Outbreak; Korean Environment Corporation: Incheon, Korea, 2009.

54. Environment Agency. Assessing the Groundwater Pollution Potential of Cemetery Developments; Environment Agency: Bristol, UK, 2004.

55. Thomas, B.W.; Sharifi, M.; Whalen, J.K.; Chantigny, M.H. Mineralizable nitrogen responds differently to manure type in contrasting soil textures. Soil Sci. Soc. Am. J. 2015, 79, 1396-1405. [CrossRef]

56. Demirbas, A. Effects of temperature and particle size on bio-char yield from pyrolysis of agricultural residues. J. Anal. Appl. Pyrolysis 2004, 72, 243-248. [CrossRef]

57. Kizito, S.; Wu, S.; Kirui, W.K.; Lei, M.; Lu, Q.; Bah, H.; Dong, R. Evaluation of slow pyrolyzed wood and rice husks biochar for adsorption of ammonium nitrogen from piggery manure anaerobic digestate slurry. Sci. Total Environ. 2015, 505, 102-112. [CrossRef] [PubMed]

58. Wen, D.; Ho, Y.S.; Tang, X. Comparative sorption kinetic studies of ammonium onto zeolite. J. Hazard. Mater. 2006, 133, 252-256. [CrossRef] [PubMed]

(C) 2017 by the authors. Licensee MDPI, Basel, Switzerland. This article is an open access article distributed under the terms and conditions of the Creative Commons Attribution (CC BY) license (http:/ / creativecommons.org/licenses/by/4.0/). 